(науковий керівник - доктор сільськогосподарських наук В. П. Кучерявий)

Хмельницький національний університет

\title{
ІНТЕНСИВНІСТЬ ТРАНСПІРАЦЇ̈ ДЕРЕВНИХ РОСЛИН У ПЕРІОД ПОСУХИ У РІЗНИХ ЕКОЛОГІЧНИХ ЗОНАХ МІСТА ХМЕЛЬНИЦЬКОГО
}

\section{Рецензент - доктор сільськогосподарських наук О. І. Любинський}

Одним із важливих чинників впливу на функціонування фізіологічних процесів $і$ оптимізаиії продуктивності дерев є водний режим. У статті проаналізовано інтенсивність транспірації деревних рослин за умов впливу несприятливих чинників природного та антропогенного походження. Результати засвідчили різницю між рівнями випаровування води у листках деревних рослин, щзо ростуть у парковій зоні та вулицях міста Хмельницького. Найбільш вразливими до посухи та впливу несприятливих чинників природного та антропогенного навантажень є гіркокаштан кінський $і$ клен гостролистий. Найбільш стійкими виявилися рослини ялини європейської, тополі пірамідальної, липи сериевидної.

Ключові слова: транспірачія, водний баланс, деревні рослини, урбоекосистема, температура, nocyxa.

Постановка проблеми. Протягом останніх десятиліть клімат України змінюється. Низка сучасних метеорологічних параметрів суттєво відрізняються від значень загальноприйнятих кліматичних норм. Так, за останні двадцять років температурні показники зросли на $0,8^{\circ} \mathrm{C}$ від встановлених норм, а середня температура січня-лютого зросла на $1-2{ }^{\circ} \mathrm{C}$ [7]. Дані тенденції зберігатимуться і в майбутньому. За прогнозами науковців Українського науково-дослідного гідрометеорологічного інституту МНС та НАНУ підвищення максимальних та мінімальних температур за рік продовжиться, тобто зими стануть м'якими та коротшими, а літо ще більш спекотним [1].

Потепління в Україні зумовлене як явищами глобального масштабу, так і змінами локального характеру, зокрема процесами урбанізації. Міста, як складний і багатокомпонентний організм, створюють особливе мікросередовище. Робота транспорту й промислових підприємств, висока щільність забудови та прогрів будівель, суцільне асфальтне чи інше тверде покриття вулиць та площ тощо підвищують загальну температуру повітря, роблять його перегрітим та надто сухим $[7,12]$. У містах простежується, на думку дослідників, явища міської пустелі [3].
Захищають міські агломерації від високих температур, наслідків парникового ефекту, від прямого сонячного опромінення, сильного перегріву, від забруднення атмосферного повітря, автотранспортних викидів і дії промислових газів, важких металів тощо зелені насадження. Вони $є$ унікальними індикаторами екологічних умов i стану навколишнього середовища, оскільки виконують роль універсального природного фільтра від техногенних забруднень [13]. Отже, озеленення урбанізованого середовища $є$ однією 3 обов'язкових умов його стійкого розвитку.

Проте значне підвищення температури, зменшення вологості грунту та повітря, скорочення кількості опадів негативно діють на біотичні угрупування. На фоні зміни кліматичних параметрів порушуються фізіолого-біологічні процеси росту й розвитку рослин, знижується їх стійкість до дії зовнішніх чинників, скорочуються терміни вегетації та інтенсивності генеративних процесів, зменшується тривалість їх життя тощо. Тому актуальною $\epsilon$ проблема вивчення комплексного впливу температурних факторів на життєвість рослин з метою добору стійких до несприятливих умов міського середовища видів, підвищення їх продуктивності та декоративності, посилення рекреаційних, санітарно-гігієнічних, естетичних та інших функцій.

Проблема пошуку оптимальних умов росту та розвитку рослин у міській зоні в умовах підвищених температур $\epsilon$ складною й багатоаспектною, оскільки залежить від багатьох факторів. Одним із важливих чинників функціонування фізіологічних процесів й оптимізації продуктивності рослин $\epsilon$ їх водозабезпечення $[12,16]$. Порушення водного режиму викликає зниження вмісту води у тканинах рослин, спричиняе втрату ними мінеральних речовин, пригнічує та припиняє їх ріст, зумовлює побуріння, засихання й опадання листя тощо [6].

Важливим фактором у визначенні водного режиму є процес транспірації. Під транспірацією розуміють процес випаровування води наземними частинами рослини. На думку науковців, во- 


\section{СТОРІНКА МОЛОДОГО ВЧЕНОГО}

на $є$ необхідною та корисною для розвитку й функціонування рослин [6]. Завдяки цьому процесу піднімається по стеблу від коренів до листків вода та мінеральні речовини, відбувається охолодження рослини, не допускається іiі перегрів тощо. Рослина володіє низкою фізіологічних особливостей, які дають змогу значною мірою регулювати віддачу води. Так, процес транспірації певною мірою залежить від ефективності поглинаючої дії поверхні коренів, структури й розмірів самої рослини, їі віку, особливостей розташування й структури листя, їх площі, розмірів, форми тощо [6, 14]. Проте інтенсивність процесу випаровування води рослиною залежить і від зовнішніх факторів, а саме: швидкості переміщення повітряних мас, підвищення температурного режиму та рівня вологості й запиленості повітря, дефіциту тиску водяної пари у ньому тощо.

Аналіз останніх досліджень і публікацій, у яких започатковано розв'язання проблеми. Питання водного режиму рослин всебічно висвітленні у низці праць сучасних вітчизняних та зарубіжних науковців. Дослідження 3 екології фізіології рослин, зокрема вивчення впливу різних умов на випаровування води рослинами презентовані Й. Баранецьким, Г. Дмитрієвою, П. Генгелем, В. Зеленським, В. Кузнецовим, А. Курсановим та іншими. Так, аналіз фізичних факторів, що впливають на інтенсивність транспірації висвітлено у наукових розвідках Л. Касьянова, В. Кузнецова. Ними встановлено, що транспірація обумовлюється впливом різних факторів, до яких належать зміни умов освітлення, струшування пагонів, за якого водяна пара виходить швидше $з$ повітряних порожнин рослин.

Особливості впливу температурних градієнтів на зелені насадження в урбоекосистемах розглянуто у працях М. Барабаш, Н. Ковальчук. Молекулярні та фізіологічні механізми стійкості рослин в умовах водного і високотемпературного стресу розглянуто у дослідженнях І. Григорюка, М. Мусієнко. Науковці О. Колісніченко, І. Григорюк, С. Грисюк, Д. Климчук на прикладі оцінки жаро- і посухостійкості саджанців каштана їстівного та гіркокаштана звичайного визначають, що висока температура зумовлює порушення функціонування продихів і зниження продуктивності рослин. У своїх наукових розвідках вони аналізують адаптивні та відновні процеси за умови дефіциту води та підвищених температур. Вивчають фізіологічні особливості багаторічних деревних культур у випадку різної водозабезпеченості Г. Єремеєв, Ж. Козюкіна, Р. Слейгер, Є. Яблонський та інші. Аналіз особливостей вод- ного режиму деревних рослин у різних екологічних зонах сучасних міст презентовано у працях Н. Нестерової. Дослідницею встановлено, що суттєвий вплив стресових чинників навколишнього природного середовища на мінливість водного режиму рослин обумовлена інтенсивністю фотосинтетичної радіації, температурним градієнтом, діапазоном активної вологи у грунті.

Методика швидкого зважування для визначення транспірації в природних умовах розроблена Л. А. Івановим, А. А. Сіліною, Ю. Л. Целькінером. Методика розрахунку інтенсивності процесу транспірації представлена у посібнику 3 лабораторних занять 3 анатомії i морфології Н. Вороніна.

Зміна в останні роки кліматичних параметрів негативно впливає на фізіолого-біологічні процеси розвитку рослин і потребує, зокрема, вивчення комплексного впливу температурних градієнтів на життєвість рослин з метою добору стійких до несприятливих умов міського середовища видів.

Метою дослідження $\epsilon$ визначення показників зміни водного режиму, а саме інтенсивності процесу транспірації деревних рослин у період посухи.

Окреслена мета реалізується через низку завдань:

- оцінка стійкості асиміляційної системи деревних рослин до повітряної посухи та впливу несприятливих чинників природного та антропогенного походження;

- особливості процесу інтенсивності транспірації деревних насаджень у різних екологічних зонах міста;

- встановлення впливу стресових чинників, а саме: водного та високотемпературного, на процес транспірації деревних рослин в умовах міста Хмельницького.

Матеріали i методика дослідження. Об'єктом обрано деревні насадження міста Хмельницького. Для проведення дослідження залучено найбільш поширені на вулицях міста і у паркових зонах види деревних рослин - гіркокаштан кінський (Aesculus hippocastanum), липа серцевидна (Tília cordáta), клен гостролистий (Acer platanoides), акація біла (Robinia pseudoacacia), ялина звичайна (Picea abies), що зростають у трьох зонах міста [13]. Перша зона - це зона умовного контролю - міський парк імені М. Чекмана (на вулиці Проскурівського підпілля), друга зона - вулиці Довженка та Тернопільська. На цих вулицях зосереджено промислові об'єкти міста, а саме: заводи «Катіон», «Новатор», «Інтерпродсервіс», третя зона - вулиці Кам'янецька 


\section{СТОРІНКА МОЛОДОГО ВЧЕНОГО}

та Проспект Миру є головними транспортними артеріями міста й відзначаються інтенсивним рухом автотранспорту. Дослідження проводилися у літній період (липень) 2015 року. Кліматичні особливості даного періоду відзначалися значно підвищеною температурою повітря, яка становила понад $30{ }^{\circ} \mathrm{C}$, його недостатньою вологістю, практичною відсутністю опадів (виключення: у липні грози - 1.07, 13.07, 14.07, які мали короткочасний характер, та дощові маси - 20.07, 26.07 - невеликої інтенсивності) [15].

3 метою визначення інтенсивності транспірації було використано ваговий метод, який базується на обліку кількості випаруваної води. Даний метод обліку інтенсивності транспірації заснований на визначенні кількості випаруваної води на основі зменшення маси листка. 3 цією метою відбирали зразки листків по 10 штук із середнього ярусу деревних рослин $[3,10]$. Листки зрізали з рослини і двічі зважували, водночас часовий інтервал між зважуваннями становив не більше 3-5 хвилин [3]. Потім зрізане листя висушували у сушильній камері при температурі $100{ }^{\circ} \mathrm{C}$ і зважували.

Для розрахунку інтенсивності транспірації визначали також площу листка. Під час визначення площі використовували наступне правило: якщо дві фігури виготовлені з одного матеріалу, то площа першої фігури відноситься до площі іншої, так само як маса першої до маси другої. 3 міліметрового паперу вирізаємо квадрат площею 25 кв. см і зважували його. Потім на цей лист паперу накладаємо дослідний листок, обводимо його контур і вирізаємо. У результаті отримуємо паперовий лист, що є рівним за площею дослідному листку. Паперовий лист зважуємо. 3 отриманих даних складаємо пропорцію:

$$
\text { Мкв/Мл = Акв /Sл }
$$

Розрахунок на суху масу дає транспіраційний коефіцієнт, який вказує скільки рослина затратила води на виробництво одиниці маси сухої органічної речовини.

Інтенсивність транспірації (Іт) обчислювали за формулою:

IT $=(($ в*60)/n)*100, де в - кількість води, що випарувалася, г; n - площа листя, см²; г- тривалість досліду, хв; 60 - коефіцієнт переведення хвилин у години; 100 - коефіцієнт переведення квадратних сантиметрів у квадратні метри.

Листя, висушене при температурі 100-105 ${ }^{\circ} \mathrm{C}$, зважували й визначали вміст у ньому води відносно сухої маси та розраховували дефіцит во-

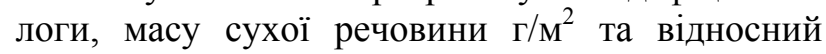
вміст вологи за формулою відповідно [8]:

$\mathrm{RWC}=((\mathrm{m} * \mathrm{~m} 2) \backslash(\mathrm{m} 1) \mathrm{m} 2)) * 100 \%$, де, $\mathrm{m}$ - маса зірваного листка, мг; m1 - маса листка після насичення водою, мг; m2 - маса абсолютно сухого листка, мг;

s - площа листової пластинки, см²; 100;

100 - коефіцієнт переведення, см² $^{2}$.

Отримані середні значення інтенсивності транспірації відібраних видів дерев презентують інформацію про активність випаровування рослин у певних екологічних зонах міста без урахування сезонних змін, вікових особливостей розвитку рослин [8].

Результати дослідження. Отримані дані засвідчили різницю між рівнем випаровування води у листках деревних рослин, що ростуть у парковій зоні та на вулицях міста. У деревних рослинах паркової зони спостерігається менша інтенсивність транспіраційних процесів у порівнянні з вуличними насадженнями (див. рис.). Ця обставина зумовлена зниженням впливу факторів антропогенного навантаження, особливостями посадки дерев, які впливають на рівень освітлення, температурного режиму, прогріву атмосферного повітря, здатністю нівелювати пряме сонячне опромінення тощо. Дані рисунку засвідчили, що у парковій зоні процес транспірації $є$ найменший у листках липи серцелистої, клена гостролистого та акації білої. У другій та третій екологічній зонах у цих деревних рослинах також рівень транспірації $є$ меншим, порівняно 3 іншими видами рослин. Дана обставина зумовлена низкою внутрішніх факторів, які впливають на регуляцію процесу транспірації, а саме: розмір і форма листя, площа й особливості його поверхні, розташування листя, вік рослини тощо $[14,16]$. У другій та третій зонах інтенсивність транспіраційних процесів у деревних насадженнях значно вища, порівняно 3 контрольною зоною. В умовах міських вулиць листя деревних рослин відзначається підвищеним рівнем транспірації, порівняно з контрольною зоною. Посилений транспортний рух, робота низки промислових підприємств, щільна забудова тощо підвищили рівень антропологічних навантажень на вуличні насадження й, відповідно, підвищили показники кліматичного градієнта. Відповідно 3 метою запобігання перегріву збільшується інтенсивність транспірації. У рослин, перегрітих високою температурою, продихи широко відкриті. Дана обставина робить їх незахищеними від значного випаровування вологи. Якщо тривалий час рослина не піддається впливам вітру чи води, листя цієї рослини починають всихатися і з часом рослина повністю втрачає листя, що не характерно для літнього періоду. 


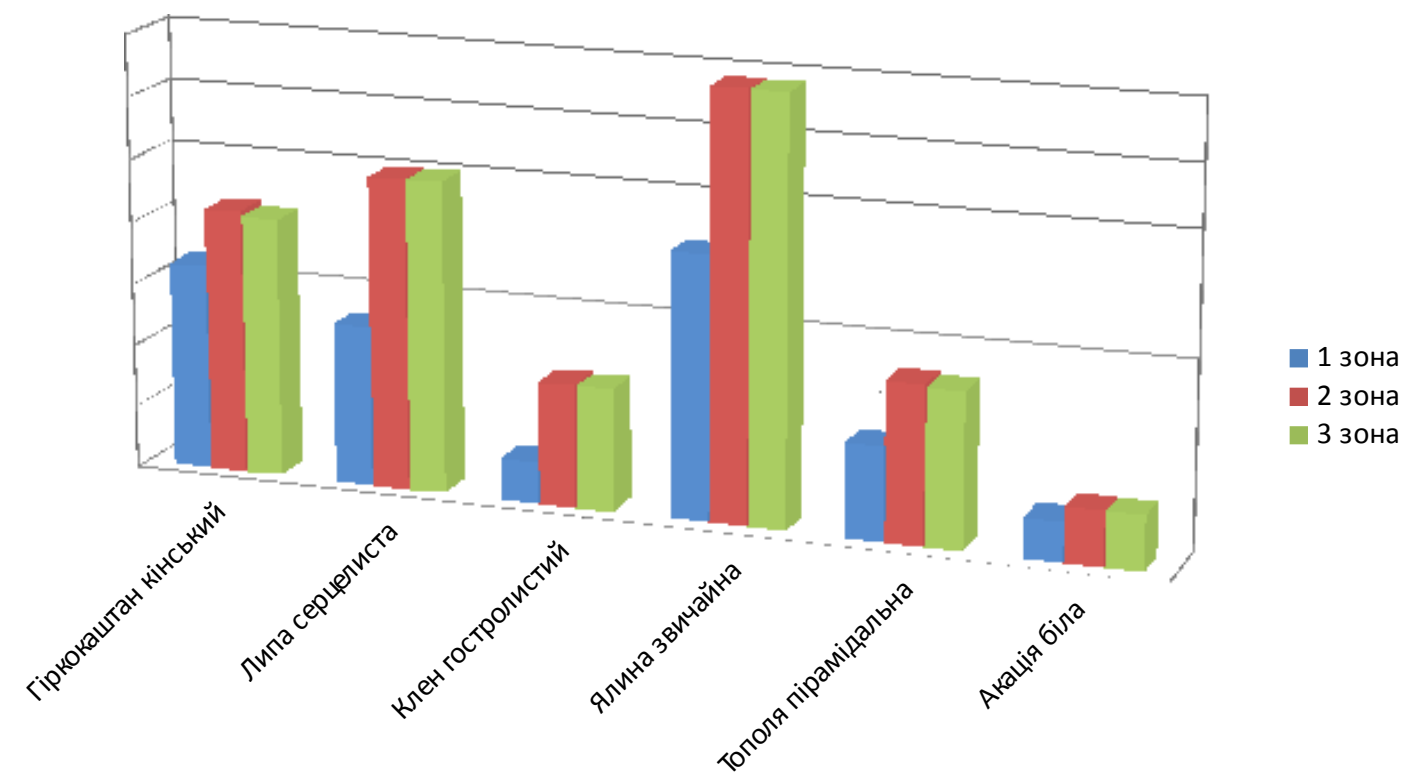

Показники транспіраційних процесів у листках деревних рослин в екологічних зонах міста Хмельницького

\begin{tabular}{|c|c|c|}
\hline Порода & Інтенсивність транспірації, г*год/м² & RWC, \% \\
\hline 1. Гіркокаштан кінський & $\begin{array}{c}\text { I зона }-3,296 \\
\text { II зона }-4,23 \\
\text { III зона }-4,15\end{array}$ & $\begin{array}{l}\text { I зона }-57,2 \\
\text { II зона }-62,7 \\
\text { III зона }-61,9\end{array}$ \\
\hline 2. Липа серцелиста & $\begin{array}{c}\text { I зона }-2,56 \\
\text { II зона }-4,97 \\
\text { III зона }-4,99\end{array}$ & $\begin{array}{l}\text { I зона }-45,2 \\
\text { II зона }-66,7 \\
\text { III зона }-66,9\end{array}$ \\
\hline 3. Клен гостролистий & $\begin{array}{c}\text { I зона }-0,6712 \\
\text { II зона }-1,965 \\
\text { III зона }-1,958\end{array}$ & $\begin{array}{l}\text { I зона }-47,9 \\
\text { II зона }-61,3 \\
\text { III зона }-61,1\end{array}$ \\
\hline 4. Ялина звичайна & $\begin{array}{c}\text { I зона }-4,231 \\
\text { II зона }-6,831 \\
\text { III зона }-6,829\end{array}$ & $\begin{array}{l}\text { I зона }-70,6 \\
\text { II зона }-92,2 \\
\text { III зона }-92,2\end{array}$ \\
\hline 5.Тополя пірамідальна & $\begin{array}{c}\text { I зона }-1,511 \\
\text { II зона }-2,531 \\
\text { III зона }-2,491\end{array}$ & $\begin{array}{l}\text { I зона }-62,5 \\
\text { II зона }-77,9 \\
\text { III зона }-76,7\end{array}$ \\
\hline 6. Акація біла & $\begin{array}{c}\text { I зона }-0,642 \\
\text { II зона }-0,8731 \\
\text { III зона }-0,8651\end{array}$ & $\begin{array}{c}\text { I зона }-74,7 \\
\text { II зона }-88,4 \\
\text { III зона }-87,9\end{array}$ \\
\hline
\end{tabular}

Відмінностей між показниками інтенсивності транспірації у другій та третій зонах практично не виявлено. Винятком є зменшення рівня випаровування води у листках тополі пірамідальної та гіркокаштана кінського на вулицях третьої зони, порівняно $з$ другою (див. табл.). Ця обставина зумовлена чутливістю рослин до пилового забруднення [4]. Пилове забруднення рослин веде до закупорювання відкритих продихів, що гальмує фізіологічні процеси, порушує водний баланс рослини, вносить зміни у іiї вегетаційний період тощо.

За вище наведеними у таблиці показниками інтенсивності транспірації найбільш стійкими до 
повітряної посухи виявилися насадження ялини звичайної, тополі пірамідальної, липи серцевидної. Серед поширених на вулицях міста видів деревних рослин найбільш вразливими до посухи та впливу несприятливих чинників природного та антропогенних навантажень є клен гостролистий, гіркокаштан кінський (див. табл.). Високотемпературний стрес спричиняє прямі й опосередковані пошкодження деревних рослин. За прямої дії високих температур повітря спостерігаються ефекти «сонячного опіку» листків і кори, біла плямистість стовбура і листків рослин, в'янення і всихання не лише листків, а й крони дерев [16]. У засушливих місцях дерева виростають менших розмірів, їх листя зазвичай дрібніше. Водний дефіцит змінює анатомію, морфологію, фізіологію і біохімію вирощування рослин.

\section{Висновки:}

1. Глобальні кліматичні зміни відбиваються на фізіологічних процесах рослин. Особливо чутливими є види в урбоекосистемах. На фоні під-

\section{БІБЛІОГРАФІЯ}

1. Балабух B. О. Зміна екстремальних погодних умов в Україні та їх прогноз до середини ХХІ століття [Електронний ресурс]. - Режим доступу : www.slideshare.net/vbalabuk.-extreme-forecasts.

2. Водний обмін рослин. - М. : Наука, 1989. - 256 с.

3. Воронін Н. С. Керівництво до лабораторних занять 3 анатомії і морфології рослин / Н. С. Воронін. - М., 1981. - 160 c.

4. Ганаба Д. В. Пилове навантаження на деревні насадження міста Хмельницького / Д. В. Ганаба // Вісник Черкаського університету. - Серія : Біологічні науки. - №19 (352). - 2015. - С. 55-60.

5. Генгель П. А. Физиология растений : учеб. пособие / П. А. Генгель. - М. : Просвещение, 1970. -234 c.

6. Григорюк I. П. Водний і високотемпературний стреси. Молекулярні та фізіологічні механізми стійкості рослин / І. П. Григорюк, М. М. Мусієнко // Фізіологія рослин в Україні на межі тисячоліть. - К., 2001. - Т.2. - С. 118-129.

7. Гребенюк Н. П., Барабаш М. Б. Про зміни температури повітря в містах України у процесі урбанізації / Н. П. Гребенюк, М. Б. Барабаш // Наукові праці УкрНДГМУ, 2004. - Вип. 253. C. $148-154$.

8. Іванов Л. А. Про методику швидкого зважування для визначення транспірації в природних умовах / Л. А. Іванов, А. А. Сіліна, Ю. Л. Цельнікер // Ботанічний журнал. - 1950. - №2. C. $30-38$. вищених температурних параметрів відбуваються зміни у водному балансі деревних рослин. Одним із наслідків тривалого водного дефіциту рослин є процес інтенсивної транспірації.

2. Різниця між рівнем випаровування води у листках деревних рослин, що ростуть у парковій зоні та на вулицях міста зумовлена зниженням впливу факторів антропогенного навантаження, особливостями посадки дерев, які впливають на рівень освітлення, температурного режиму, прогрів атмосферного повітря тощо.

3. Найбільш стійкими до повітряної посухи за показниками інтенсивності транспірації у місті Хмельницькому виявилися рослини ялини європейської, тополі пірамідальної, липи серцевидної. Серед поширених на вулицях міста видів деревних рослин найбільш вразливими до посухи та впливу несприятливих чинників природного та антропогенних навантажень є клен гостролистий, гіркокаштан кінський.

9. Касьянова Л. М. Екологія рослин. Водний обмін / Л. М. Касьянова. - М. : Наука, 1994. - 287 с.

10. Кузнєцов В. В., Дмитрієва Г. А. Фізіологія рослин / В. В. Кузнєцов, Г. А. Дмитрієва. - М. : Вища школа, 2005. - 720 с.

11. Ковальчук Н. Особливості впливу температурних градієнтів на зелені насадження м. Луцька / Наталія Ковальчук // Вісник Львівського університету. - Серія біологічна. - 2006. Вип.41. - С. 36-39.

12. Машинский Л. О. Озеленение городов / Л. О. Машинский. - М. : изд-во АН СССР, 1951. C. 222-224.

13. Нестерова Н. Г., Григорюк І. П. Особливості водного режиму деревних видів рослин в екологічних умовах м. Київ / Н. Г. Нестерова, I. П. Григорюк // Збалансоване природокористування. - №2-3. - 2013. - С. 89-95.

14. Оцінка вразливості та заходи з адаптації до зміни клімату. Хмельницький [Електронний ресурс]. - Режим доступу : http://necu.org.ua/otsinka vrazlyvosti-ta-zahody-z-adaptatsiyi-do-zminy-klimatumist-lviv-odesa-hmelnytskyy-ta-uzhhorod/.

15. Погода мета [Електронний ресурс]. - Peжим доступу : http://pogoda.meta.ua/Khmelnytska/ Khmelnytskyi/Khmelnytskyi/archive/2015/.

16. Фізіологія рослин / [за ред. А. Л. Курсанова]. - М. : вид-во «Наука», Академія наук СРСР. Т.11. $-1964 .-558$ с. 